\title{
The Nexus Between Public Diplomacy and Military Diplomacy in Foreign Affairs and Defense Policy
}

\author{
Göran Swistek *
}

\section{Introduction}

The idea of "public diplomacy" was implemented approximately a century ago as the purely civilian aspect of diplomacy, which aimed to inform foreign populations and citizens about the goals of a given country's foreign policy through the use of information and cultural programs. ${ }^{1}$ Within the framework of the Clausewitzian philosophy, which held that war "is the continuation of politics by other means," the military was always linked to the diplomatic realm, but was never part of it. ${ }^{2}$ On the other hand, for a long time "military diplomacy" meant simply the business of military attachés; their mission was to be "the Nation's eye and ears abroad in the days before satellite photography and sophisticated electronic collection techniques." 3

Along with the changes that the past several decades have seen in the makeup of the international arena, particularly regarding the new constellation of alliances, revised goals of foreign policies, and altered threat assumptions, the content of public diplomacy has changed, and its targeted programs have expanded. ${ }^{4}$ At the same time, the understanding and definition of the concept of security has changed since the collapse of the Iron Curtain and the breakdown of the Soviet Union. Nowadays, security is defined above all by the notion of a "comprehensive approach." Security is now viewed as a set of interconnections between civilian and military means and approaches, while the use of military force remains a last resort. Therefore, programs and means from the areas of military and public diplomacy have received increased attention and have gained a more prominent status.

For this reason, this essay will attempt to trace the close relations of modern defense strategies, policies, and diplomacies. The guiding research question for this essay shall be, Is there in modern foreign affairs and defense policy a relation between military diplomacy and public diplomacy? If so, what characterizes this relation? Along that line,

\footnotetext{
Commander j.G. Dipl. pol. Göran Swistek MCGI is a naval officer, currently CO of FGS FRETTCHEN and holds a degree in Political Science as well as in Leadership and Management. He is alumni of the LPASS 2011. He is currently participating in the Master in International Security Studies at the George C. Marshall Center. His fields of expertise are International Relations; Security Politics and Strategy; Peace and Conflict Research and Modern Warfare.

1 Walter R. Roberts, "What is Public Diplomacy? Past Practices, Present Conduct, Possible Future," Mediterranean Quarterly 18:4 (2007): 37.

2 Carl von Clausewitz, On War, Chapter 1, Para. 24 (Project Gutenberg E-Book No. 1946, 25 February 2006); available at http://www.gutenberg.org/files/1946/1946-h/1946-h.htm.

3 Timothy C. Shea, “Transforming Military Diplomacy,” Joint Force Quarterly 38 (2005): 50.

4 Roberts, "What is Public Diplomacy?"
} 
this essay will examine the nexus between public diplomacy and military diplomacy, with the assumption that international relations and defense policies are aimed at overlapping areas, especially when it comes to diplomacy. The hypothesis therefore can be encapsulated thus: without naming it in official policy documents, and without a focused strategy, an area has recently developed where public diplomacy and military diplomacy are proceeding in concert, with a common toolset. I will use the German armed forces as a special case study in order to demonstrate that they have actually been practicing public diplomacy within their military posture for decades.

As a first step, the essay will offer a general overview about the idea, definitions, and different concepts of public diplomacy, which will provide the basic background for further observations. In contrast, a brief examination of the idea and concept of military diplomacy will show the approach from a different perspective. In a third step, the essay will highlight common strategies and tools in order to display areas of overlap and similarity. Following these sections, the essay will present two case studies of the German Armed Forces, which will demonstrate the hypothesis on the foundation of the observation drawn from the first two steps. Finally, the essay's conclusion will draw some general findings on the relationship between public and military diplomacy in our times.

\section{The Concept of Public Diplomacy}

Public diplomacy is to some extent part of a traditional branch of diplomacy, one that refers to government sponsored-programs and initiatives that aim to influence and inform foreign audiences. These programs are also sometimes called "international information" or "cultural" programs. Usually these programs are used to transmit a certain message regarding a nation's foreign policy, political aims, economic cooperation efforts, or even touristic developments.

It is inherent in the concept of public diplomacy that the addressees of the activities carried out under its banner are mainly non-governmental actors. However, public diplomacy does seek to encourage international understanding and engage in dialogue between the involved nations and decision makers. Therefore, traditional public diplomacy efforts aimed to create this understanding with information, language, and cultural programs. Public diplomacy programs were built around two pillars: the first pillar, that of informing, can be compared to a traditional public relations element; the second pillar consists of creating understanding of policies and ideologies. The second part in particular constituted a two-way process, where a nation tried to make populations abroad understand its particular policies while also trying to gain understanding of the policies of foreign countries. Detailed individual actions within this two-pillar approach ranged for example from common academic programs and exchanges, cultural cooperation, outreach programs, and tourism promotion, to the establishment of language institutes and the organization of cooperative scientific and artistic projects.

In recent years, along with the development of a comprehensive approach to a new range of security threats and to changes within the perception of security, public diplomacy again moved more toward a focus on foreign relations as a strategy, a tool for 
cross-national interaction, and a mechanism to promote the development of interdependences and therefore to support efforts to maintain and expand peace.

Therefore a new pillar was added to the edifice of public diplomacy: influence on foreign policy. This element aims to have an impact on decisions and decision makers in foreign governments. ${ }^{5}$ Even when the actions of public diplomacy largely originate from governments and governmental bodies, however, it does not seek to have a direct impact on foreign governments and decision makers. By creating a positive climate among foreign populations, the countries that are generating public diplomacy campaigns try to facilitate the goals and objectives of their foreign policy. ${ }^{6}$

The ambassador was once the main player within the field of public diplomacy, but nowadays the actors involved in such campaigns are diverse in nature and large in number. The ambassador, as the senior diplomat in a given foreign country, still remains the primary vehicle for diplomatic messages and efforts, but actions on the ground (and particularly away from the embassy) are usually the responsibility of other governmentfunded bodies, multinational organizations, cooperative networks, or non-governmental organizations. $^{7}$ Along these lines, the military has also recently gained more responsibility within the area of public diplomacy in some nations.

\section{What is Military Diplomacy?}

Parallel to the definition of public diplomacy, the term military diplomacy (or, as it is often also called, defense diplomacy) was and is still very closely linked to the role of the military attaché. ${ }^{8}$ The attaché, as the counterpart of the ambassador, is a diplomat in uniform with full diplomatic status whose duty was once to observe and assess military developments in a foreign country, as well as to maintain a close relationship with the foreign military elite. This practice emerged as part of nineteenth-century European diplomacy, and continued nearly unchanged until the mid-1980s. ${ }^{9}$ An important shift in the nature and purpose of international military relations took place along with the fall of the Iron Curtain. With the change in the perception of security in favor of the comprehensive approach and enhanced security, the role of the military attaché and his duties expanded as well. In addition, he is no longer the only military actor with a role to play in the area of military diplomacy. The term and modern perception of military diplomacy could be defined as follows: "To provide forces to meet the varied activities undertaken by the Ministry of Defense to dispel hostility, build and maintain trust, and as-

\footnotetext{
Roberts, "What is Public Diplomacy?," 45.

Ibid., 46.

Ibid., 50.

Shea, "Transforming Military Diplomacy," 50.

Andrew Cottey and Anthony Forster, "Introduction to Reshaping Defence Diplomacy: New Roles for Military Cooperation and Assistance," in Reshaping Defence Diplomacy: New Roles for Military Cooperation and Assistance (London: Routledge, Chapman \& Hall, 2004).
} 
sist in the development of democratically accountable armed forces, thereby making a significant contribution to conflict prevention and resolution." 10

The traditional role of the armed forces was defined by their capability and preparedness to use force and pose a threat for the purpose of defense, deterrence, compulsion, or intervention. ${ }^{11}$ Military diplomacy nowadays is primarily a peacetime activity, and has become a major task for armed forces and their responsible ministries. It is framed by cooperation among allies and other foreign countries, especially those undergoing a process of transition towards post-conflict and democratic societies, where it can be used as a tool to promote modern foreign and security policy. ${ }^{12}$ Under the framework of a comprehensive approach towards security, military diplomacy is today one of the supporting pillars.

Individual activities summed up under the concept of military diplomacy from the perspective of the United States are:

- Creating bilateral and multilateral contacts between senior military and civilian defense officials

- Appointment of defense attachés

- Bilateral defense cooperation agreements

- Training activities for foreign military and civilian defense personnel

- Providing expertise and advice on the issues of democratic control of armed forces, defense management, and military technical areas

- Exchanges between military personnel

- Providing military support and aid with material and equipment. ${ }^{13}$

This extract compares very much to the major tasks and individual missions identified by the U.K. Ministry of Defense in their policy paper on defense diplomacy published in December 2000. With this paper, the United Kingdom government took the lead by emphasizing the increased role of military diplomacy as a primary duty for the armed forces. The named major tasks in this paper are:

- Arms control, non-proliferation, and confidence- and security-building measures

- Outreach activities

- Other activities covering military assistance not covered under outreach. ${ }^{14}$

10 United Kingdom Ministry of Defence, "Defence Diplomacy," MoD Policy Paper 1 (December 2000), 2; available at www.mod.uk/DefenceInternet/AboutDefence/CorporatePublications/ PolicyStrategyandPlanning/PolicyPapers/PolicyPaperNo1DefenceDiplomacy.htm

11 Cottey and Forster, "Introduction to Reshaping Defence Diplomacy."

12 Ibid.

13 Ibid., Table 1.

14 U.K. Ministry of Defence, "Defence Diplomacy," 5-14. 
Under these broad tasks, the U.K. MoD identified the following detailed missions for its military to pursue as part of its diplomatic efforts:

- Training courses and education programs

- Providing personnel for training, via loan services as well as civilian and military advisers

- Visits by ships, aircraft and other military units

- Visits by ministers and by military and civilian personnel at all levels

- Staff talks, conferences, and seminars to improve mutual understanding

- Exchanges of personnel

- Joint exercises. $^{15}$

Overall it can be observed that military diplomacy has undergone a shift toward becoming a tool in crisis prevention, early warning, and post-conflict rebuilding in the huge area of foreign and security policy. It is used in efforts to create stability and security by changing the attitudes and perception of parties to a conflict; therefore it "is this 'disarmament of the mind' that characterizes" military diplomacy. ${ }^{16}$ Thus the central aim for the further development of security can simply be described as building partnerships and partnership capacity.

\section{Common Strategy and Tools}

After having reviewed the initial concept and the development of public diplomacy, as well as the perhaps less familiar field of military diplomacy, it is clear that these two efforts have developed overlapping areas of responsibilities and activities in modern foreign and security policies. Together, they aim to inform and influence foreign audiences by the use of cooperation-, information-, and trust-building programs. While military diplomacy initially pretended to focus only on the very sensitive area of security and the use of force, it has over time developed a broad set of tools targeted on such issues as creating understanding, building mutual trust, and influencing other officials, not just senior representatives from the military but also civil servants working in the wider field of security and diplomacy. Public diplomacy, by contrast, is primarily focused only on the civilian population in foreign countries, usually in order to avoid giving any impression of being linked to the military, and therefore generally takes advantage of the reputation of non-governmental organizations. As a result, both concepts seem to have their own areas of responsibility, and work simultaneously on parallel tracks, even if they do also have individual overlapping tasks. In an era where a comprehensive approach to security is the goal - where security is a common task across all fields of politics and for all government ministries - such a duplication of effort cannot be avoided, and even seems to be necessary in order to approach security issues on different levels and in dif-

15 Ibid., 4-5.

16 Ibid., 4. 
ferent settings. There are parts of a society who will reject cooperation with military bodies, and at the same time there are parts of a society that are easier to approach from the military point of view. The same observation also applies in the case of public diplomacy. The traditional distance between both areas, and the reservations each has had regarding the other, have become blurred and obsolete. The only remaining objection against this removal of a strict separation between military and public diplomacy is the often used allegation that public diplomacy (and with it, the civil society) might become instrumentalized by the military. With a phased and synchronized approach towards security issues and problems in foreign countries, this anxiety can be alleviated.

\section{Selective Case Study of the German Armed Forces}

The central principle in German Foreign and Security Policy was and still is "never again, never alone, politics before force." 17 For that reason, over the past sixty years Germany has objected and continues to object to any unilateral power and military aligned foreign policy. Committed to the values of Western democracies, Germany embedded its Foreign and Security Policy in its practices of cooperation with its allies, the transnational institutions in which it participates, and in the European system of collective security. ${ }^{18}$ Considered only on its own, Germany's Foreign and Security Policy represents a specific vision of civil society. Diplomacy, cooperation, development aid, and cultural education programs are major elements of Germany's international relations. This has been a tradition of Germany's approach to international relations since the end of the Second World War, and is reflected in Germany's concept for the creation and deployment of its armed forces. For that reason, the German Foreign and Security Policy was until the end of the Cold War ironically referred to as "checkbook diplomacy," describing Germany's extreme reluctance to use force, and its emphasis instead on well-funded language, cultural, and development programs in international relations. This attitude - and, with it, the general image of Germany's foreign policy - changed with the first deployments of German forces in NATO and UN operations after the fall of the Iron Curtain and the reunification of Germany. However, the basic character of Germany's “checkbook diplomacy" still provides the foundation of today's Foreign and Security Policy.

Along that line, the German Navy developed a field of activities that were often grouped together under the rubric "Ambassador in Blue." This approach never achieved the status of a complete conception, but with several individual and internal naval taskings, it represented a combination of activities carried out from the 1970s until today. A

17 Sebastian Harnisch and Hanns W. Maull, "Conclusion: Learned its Lesson Well? Germany as a Civilian Power Ten Years after Unification," in Germany as a Civilian Power: The Foreign Policy of the Berlin Republic, ed. Harnisch and Maull (Manchester: Manchester University Press, 2001), 128-56.

18 Christine Streichert, "Deutschland als Zivilmacht," Trierer Arbeitspapiere zur Internationalen Politik 11 (Trier: Universität Trier, 2005), 4-5; available at www.deutsche-aussenpolitik.de/ resources/tazip/tazip11.pdf. 
major pillar in this field of activity was and is related to visits by German naval ships to foreign countries. The duty for the ships engaged in these visits is to represent Germany through hosting foreign officials, representing developments in German ship building and naval warfare technology, provide support for training efforts for foreign naval personnel, provide a platform for German senior government and military officials, and deliver donations from governmental as well as non-governmental organizations to foreign development projects. These activities supported the work of the German Defense or Naval Attaché in this foreign country, and were focused on creating improved relations, supporting a range of development programs, providing a better understanding of German politics, as well as establishing business relations between these countries and Germany.

Another area where the German armed forces developed unique skills as well as special programs in the overlapping sector between military diplomacy and public diplomacy - and, in the process, took a leading role among its allies - is the critical field of civilian-military cooperation (CIMIC). Today the sector of civilian-military cooperation is an independent organizational part of the German military (called ZMZ). ${ }^{19}$ It develops, deploys, and coordinates activities and programs focused on security, development, and threat identification and protection within Germany as well as in foreign countries, and does so by coordinating efforts between governmental and non-governmental organizations together with the armed forces. Under the theme of "no development without security," the German government announced in 2004 the creation of provincial reconstruction teams (PRT) and their deployment to Afghanistan. ${ }^{20}$ These teams are made up of a combination of workers, engineers, and representatives of development agencies and non-governmental organizations as well as soldiers from the armed forces. Together they are tasked with pushing forward the reconstruction of civilian sites in Afghanistan, redeploying development programs, ensuring the security of foreign non-combatants, and bolstering the reputation of German aid workers and soldiers within Afghanistan. Along with the task of reconstruction and creating the basis for a future secure environment, these teams are also focused on establishing connections to local Afghan authorities as well as senior Afghan leaders. From the point of view of civilian and non-governmental organizations, this project was approached with significant hesitation, as they worried about losing their reputation as independent and charitable actors among the Afghan population. The statistical data is still very sparse, and the timeframe is too short in order to draw any conclusions about the success and achievements of these teams at this point, but governmental officials are already emphasizing the importance of such projects for the overall conflict transformation effort and future integration of German

19 More details on German CIMIC activities and structures are available at: www.auswaertigesamt.de; www.bmvg.de; www.bundesregierung.de; www.bundeswehr.de; www.deutscheaussenpolitik.de. The current concept can be reviewed at: http://www.streitkraeftebasis.de/ portal/a/streitkraeftebasis/uleist/zmzi.

20 Peter Runge, "Helfer in Uniform? Militäreinsätze in der humanitären Hilfe," in Wissenschaft \& Frieden, no. 4 (2006), special issue on "Zivil-militärische Zusammenarbeit"; available at http://www.wissenschaft-und-frieden.de/seite.php?artikelID=0463. 
personnel into partnership programs. Criticism of the teams was levied on the point that Germany should never engage in operations that would create a blurred mandate between armed forces and non-governmental or charitable organizations, as both would ultimately lose their basic legitimacy. $^{21}$

\section{Conclusion}

In summary, public diplomacy and military diplomacy have developed over the past century based on different assumptions about international relations, and have therefore been focused on separate areas and activities. With the more complex and interdependent approach towards security issues in a newly interconnected world, both areas have developed overlapping responsibilities and activities, where both are aimed at common achievements like creating an understanding of a given country's politics, building cooperation and partnership, and supporting processes of stabilization with respect to regional and international security. At the same time, both areas still remain distinct, with unique goals and activities, as they are mainly used in different settings.

Military cooperation - and therefore also military diplomacy-have primarily been part of the toolkit of international realpolitik in the preservation of a balance of power by supporting allies and counterbalancing enemies. Today, military diplomacy is used to build and maintain partnership capacities with former opponents and newly engaged partners. It has become one of the first programs deployed in post-conflict societies in order to consolidate the absence of fundamental violence. But military diplomacy has also a legitimate role to play in peaceful and allied societies, where cooperation and partnership (especially in the sensitive area of security) requires continued common efforts. Creating enduring and lasting security and stability remains the overarching goal.

Similar assumptions can be made about the sector of public diplomacy. Once merely a tool used in the attempt to inform and communicate a common understanding of a given country's policies to foreign communities, it has become today an integral part of a wider approach to international security, where a major task is the attempt to influence foreign societies through the pathways of civil society. But it is less an attempt to persuade foreign societies, rather than to provide support in the process of self-determination for a free, equal, and independent society.

Both examined areas have developed, as was suggested, in line with today's general conditions in international relations to become very closely linked areas in the field of foreign and security policy. Both can and should be used as tools in both peacetime and in conflict scenarios to support efforts for stability and security.

21 Ibid. 


\section{Bibliography}

Cottey, Andrew, and Anthony Forster. "Introduction to Reshaping Defence Diplomacy: New Roles for Military Cooperation and Assistance." In Reshaping Defence Diplomacy: New Roles for Military Cooperation and Assistance. London: Routledge, Chapman \& Hall, 2004.

Defence, United Kingdom Mi. Defence Diplomacy, Policy Paper 1. MoD , 2000.

Harnisch, Sebastian, and Hanns W. Maull. "Conclusion: Learned its Lesson Well? Germany as a Civilian Power Ten Years after Unification." In Germany as a Civilian Power: The Foreign Policy of the Berlin Republic, 128-56. Manchester: Manchester University Press, 2001.

Roberts, Walter R.. "What is Public Diplomacy? Past Practices, Present Conduct, Possible Future." Mediterranean Quarterly 18, no. 4 (2007): 37.

Runge, Peter. "Helfer in Uniform? Militäreinsätze in der humanitären Hilfe." Wissenschaft \& Frieden, special issue on "Zivil-militärische Zusammenarbeit, no. 4 (2006).

Shea, Timothy C.. "Transforming Military Diplomacy." Joint Force Quarterly 38, no. 50 (2005).

Streichert, Christine. Deutschland als Zivilmacht In Trierer Arbeitspapiere zur Internationalen Politik . Vol. 11 . Trier: Universität Trier, 2005.

von Clausewitz, Carl. On War. Project Gutenberg E-Book No. 1946, 2006. 